\title{
Editorial
}

\section{Autoinflammation It Is!}

\author{
Eugen Feist (1)
}

check for updates

Citation: Feist, E. Autoinflammation It Is! J. Clin. Med. 2021, 10, 5157. https://doi.org/10.3390/jcm10215157

Received: 26 October 2021

Accepted: 2 November 2021

Published: 3 November 2021

Publisher's Note: MDPI stays neutral with regard to jurisdictional claims in published maps and institutional affiliations.

Copyright: (C) 2021 by the author. Licensee MDPI, Basel, Switzerland. This article is an open access article distributed under the terms and conditions of the Creative Commons Attribution (CC BY) license (https:// creativecommons.org/licenses/by/ $4.0 /)$.
Department of Rheumatology, Helios Clinic Vogelsang-Gommern, Cooperation Partner of the Otto-von-Guericke University, Sophie-von-Boetticher-Straße 1, 39245 Vogelsang-Gommern, Germany; Eugen.Feist@helios-gesundheit.de

In recent years, we have entered a new era full of insights into exciting pathways and improved management of a distinct class of inflammatory conditions. Under the umbrella of auto-inflammation, several so far seemingly unconnected diseases have been summarized and separated from autoimmune conditions in particular. Initially, the striking difference became clear for classical monogenetic periodic fever syndromes, where the innate immune system plays a dominant role via the impact of a specific cytokine signature.

In this Special Issue of the Journal of Clinical Medicine, we find a diverse spectrum of excellent contributions to this topic. Articles on the current knowledge of cryopyrinassociated periodic syndromes [1] and proteasome-associated autoinflammatory syndromes [2] provide us with valuable advice for diagnosis and treatment of these rare conditions in clinical practice.

The field of auto-inflammation has further extended to more complex polygenetic disorders. In this context, two diseases, namely adult-onset Still's disease [3] and gouty arthritis [4], are focused on in this Special Issue. Both contributions show that in these clinically and mechanistically diverse diseases, the main symptoms are caused by a very similar cytokine signature referring to interleukin 1 as the main driver. This knowledge has also paved the way for new targeted and highly effective therapies.

This Special Issue on auto-inflammation also contains relevant contribution that have been rarely addressed in such detail elsewhere. To highlight just a few points, one can read about the current options of imaging in auto-inflammation [5] with special attention to IgG4 related diseases [6] or about the issue of dysphagia in myositis [7]. Furthermore, this Special Issue also contains valuable original work, such as studies providing basic data on a novel variant of TNF receptor-associated periodic syndrome [8], drug hepatotoxicity in the treatment of gouty arthritis [9], the impact of certain anti-rheumatic drugs on DNA repair [10], genetic background in association with response to anti-rheumatic drugs [11], and the impact of IL1-inhibition on the cytokine milieu in adult-onset Still's disease [12].

Auto-inflammation can also cause life-threatening complications often in association with hyper-inflammation or cytokine storm. Nowadays, everyone is familiar with the issue of severe COVID-19 infections due to an overwhelming and disturbed cytokine signaling. Of note, during this pandemic disaster, special attention has been attributed to the group of patients receiving immunosuppressive therapy, which typically includes those with auto-immune and -inflammatory diseases. In this Special Issue, we are able to publish one of the earliest observations with respect to rare auto-inflammatory diseases. The risk for severe acute COVID-19 disease was mild to moderate in these patients [13]. However, even after resolution of infection, there was an impact on disease activity in these cases. With respect to hyper-inflammation, the critical role of interferons has recently been highlighted. In this context, we can also learn a lot from complications in auto-inflammatory diseases, such as macrophage activation syndrome [14].

Research in the field of auto-inflammation remains in its infancy. Currently, we cannot place each manifestation in a distinct category. To solve this problem, the concept of systemic undefined recurrent fevers has recently been introduced [15]. We should be aware that many of these diseases are still under-recognized, which requires our special 
attention. Overall, this Special Issue on auto-inflammation is of valuable interdisciplinary information. I am very thankful to the authors for their contribution to this constantly growing field and wish you a fruitful reading.

Conflicts of Interest: The author declares no conflict of interest.

\section{References}

1. Welzel, T.; Kuemmerle-Deschner, J.B. Diagnosis and Management of the Cryopyrin-Associated Periodic Syndromes (CAPS): What Do We Know Today? J. Clin. Med. 2021, 10, 128. [CrossRef] [PubMed]

2. Goetzke, C.C.; Ebstein, F.; Kallinich, T. Role of Proteasomes in Inflammation. J. Clin. Med. 2021, 10, 1783. [CrossRef] [PubMed]

3. Mitrovic, S.; Fautrel, B. Clinical Phenotypes of Adult-Onset Still's Disease: New Insights from Pathophysiology and Literature Findings. J. Clin. Med. 2021, 10, 2633. [CrossRef] [PubMed]

4. Galozzi, P.; Bindoli, S.; Doria, A.; Oliviero, F.; Sfriso, P. Autoinflammatory Features in Gouty Arthritis. J. Clin. Med. 2021, 10, 1880. [CrossRef] [PubMed]

5. Ziegeler, K.; Eshed, I.; Diekhoff, T.; Hermann, K.G. Imaging of Joints and Bones in Autoinflammation. J. Clin. Med. 2020, 9 , 4074. [CrossRef] [PubMed]

6. Yuan, W.-H.; Li, A.F.-Y.; Yu, S.-Y.; Chen, Y.-Y.; Wu, C.-H.; Hsu, H.-C.; Lirng, J.-F.; Guo, W.-Y. Evaluate the Differences in CT Features and Serum IgG4 Levels between Lymphoma and Immunoglobulin G4-Related Disease of the Orbit. J. Clin. Med. 2020, 9 , 2425. [CrossRef] [PubMed]

7. Labeit, B.; Pawlitzki, M.; Ruck, T.; Muhle, P.; Claus, I.; Suntrup-Krueger, S.; Warnecke, T.; Meuth, S.G.; Wiendl, H.; Dziewas, R. The Impact of Dysphagia in Myositis: A Systematic Review and Meta-Analysis. J. Clin. Med. 2020, 9, 2150. [CrossRef] [PubMed]

8. Zegarska, J.; Wiesik-Szewczyk, E.; Hryniewiecka, E.; Wolska-Kusnierz, B.; Soldacki, D.; Kacprzak, M.; Sobczynska-Tomaszewska, A.; Czerska, K.; Siedlecki, P.; Jahnz-Rozyk, K.; et al. Tumor Necrosis Factor Receptor-Associated Periodic Syndrome (TRAPS) with a New Pathogenic Variant in TNFRSF1A Gene in a Family of the Adult Male with Renal AA Amyloidosis-Diagnostic and Therapeutic Challenge for Clinicians. J. Clin. Med. 2021, 10, 465. [CrossRef] [PubMed]

9. Oh, Y.-J.; Moon, K.W. Combined Use of Febuxostat and Colchicine Does Not Increase Acute Hepatotoxicity in Patients with Gout: A Retrospective Study. J. Clin. Med. 2020, 9, 1488. [CrossRef] [PubMed]

10. Reddig, A.; Voss, L.; Guttek, K.; Roggenbuck, D.; Feist, E.; Reinhold, D. Impact of Different JAK Inhibitors and Methotrexate on Lymphocyte Proliferation and DNA Damage. J. Clin. Med. 2021, 10, 1431. [CrossRef] [PubMed]

11. Favoino, E.; Urso, L.; Serafino, A.; Misceo, F.; Catacchio, G.; Prete, M.; Perosa, F. HLA Allele Prevalence in Disease-Modifying Antirheumatic Drugs-Responsive Enthesitis and/or Arthritis Not Fulfilling ASAS Criteria: Comparison with Psoriatic and Undifferentiated Spondyloarthritis. J. Clin. Med. 2021, 10, 3006. [CrossRef] [PubMed]

12. Ghannam, K.; Zernicke, J.; Kedor, C.; Listing, J.; Burmester, G.-R.; Foell, D.; Feist, E. Distinct Effects of Interleukin-1 $\beta$ Inhibition upon Cytokine Profile in Patients with Adult-Onset Still's Disease and Active Articular Manifestation Responding to Canakinumab. J. Clin. Med. 2021, 10, 4400. [CrossRef] [PubMed]

13. Welzel, T.; Samba, S.D.; Klein, R.; van den Anker, J.N.; Kuemmerle-Deschner, J.B. COVID-19 in Autoinflammatory Diseases with Immunosuppressive Treatment. J. Clin. Med. 2021, 10, 605. [CrossRef] [PubMed]

14. Di Cola, I.; Ruscitti, P.; Giacomelli, R.; Cipriani, P. The Pathogenic Role of Interferons in the Hyperinflammatory Response on Adult-Onset Still's Disease and Macrophage Activation Syndrome: Paving the Way towards New Therapeutic Targets. J. Clin. Med. 2021, 10, 1164. [CrossRef] [PubMed]

15. Papa, R.; Penco, F.; Volpi, S.; Sutera, D.; Caorsi, R.; Gattorno, M. Syndrome of Undifferentiated Recurrent Fever (SURF): An Emerging Group of Autoinflammatory Recurrent Fevers. J. Clin. Med. 2021, 10, 1963. [CrossRef] [PubMed] 